\title{
28 Research Square \\ Credit and Liquidity Risk Assessment of NCC Bank: A Correlational Analysis
}

Md. Ataur Rahman Chowdhury ( $\square$ ataur152@gmail.com )

University of Dhaka

Research Article

Keywords: Credit Risk, Banks, Bangladesh, Liquidity

Posted Date: December 29th, 2021

DOI: https://doi.org/10.21203/rs.3.rs-1197595/v1

License: (c) (i) This work is licensed under a Creative Commons Attribution 4.0 International License.

Read Full License 


\section{Abstract}

Credit risk and default risk are two interchangeable terms. Credit risk arises mainly from the lending, trade finance, leasing, and treasury business. This can be described as a potential loss from a counterparty's failure to perform as per contractual agreement with the bank being financially incapable or unwilling to repay it. Financial incapability arises when the creditor's source of earning becomes volatile. The unwillingness comes from the creditor's tendency to cheat and to make a bulk grain from the fraudulent activities. At a stretch, credit risk for the bank illustrates that the bank's performing loan portion can turn into non-performing ones. And that will decrease the recovery rate of the loan extended, and, as a result, the bank will face trouble providing the required interest amount by the depositors. Gradually the bank will become insolvent and maybe some days a bankrupt one.

\section{Introduction}

Banks are the pillars of the financial system. Especially in Bangladesh, the banking system's health is vital because the capital market is little developed here. As the banks are still the major sources of credit and exercise great influence on the financial system, the country's banking system must be in good health in investment activities, meeting all kinds of finance and related matters' needs. Over the years, NCC Bank has built itself as one of the strong and important members of Bangladesh's financial sector and plays a significant role in extending the private sector of the economy. The bank is pledge \& bound to perform even better in the coming years, opening new branches, adding new and better products and service to its customer at their doorsteps. Without an efficient policymaker and management team, it is not possible to achieve the desired goal. NCC Bank also needs that to accomplish its mission. The next few sections will present the board of directors, the management term, the organizational structure, and each division's responsibilities.

\section{Stress Testing}

Stress testing is a simulation technique used to determine different financial institutions' reactions under a set of exceptional but plausible assumptions through a battery of tests. At the institutional level, stress testing techniques provide a way to quantify the impact of changes in several risk factors on the institution's assets and liabilities portfolio. For instance, a portfolio stress test makes a rough estimate of portfolio value using a set of exceptional but plausible events in abnormal markets. However, one of the limitations of this technique is that stress tests do not account for the probability of these exceptional events. For this purpose, other techniques, such as VAR (value at risks) models, are used to supplement the stress tests. These tests help manage risk within a financial institution to ensure optimum allocation of capital across its risk profile.

Even after following all the necessary techniques, a shock from the credit is unavoidable. Some borrowers will be defaulter at the end of the day whatever the safety measures are taken into account. What's the susceptibility of an $\mathrm{n}$ respect of a major shock in this regard is the major issue to be concerned 
about. NCC Bank Limited is a first-generation bank. It has a strong customer base. But still, profit is fluctuating over the years. Stability in respect of NPL is not consistent. So the test of Stress regarding the credit shock is assed below, given a narrow theoretical overview regarding this issue. Though stress testing is done considering other shocks also. But the matter of concern here is the credit shock.

\section{Credit Shock}

The stress test for credit Shock/risk assesses the impact of the increase in nonperforming performance. Loans of the bank/FI. The first deals with the increase in the NPLs and the respective provisioning. The three scenarios shall explain the impact of $1 \%, 2 \%$, and $3 \%$ of the total performing loans directly downgraded to bad/loss category having $100 \%$ provisioning requirement. The second deals with the negative shift in the NPLs categories and hence the increase in respective provisioning. The three scenarios shall explain the impact of $50 \%, 80 \%$, and $100 \%$ downward shifts in the NPLs categories. For example, for the first level of shock, $50 \%$ of the SMA shall be categorized under substandard, $50 \%$ of the substandard shall be categorized under doubtful, and $50 \%$ of the doubtful will be in the bad/loss category. The third deals with the fall in the forced sale value (FSV) of mortgaged collateral. The collateral's forced sale values shall be given shocks of $10 \%, 20 \%$, and $40 \%$ decline in the forced sale value of mortgaged collateral for all three scenarios, respectively. The fourth deals with the increase of the NPLs in particular 1 or 2 sectors, i.e., garments \& Textiles and the respective provisioning. The three scenarios shall explain the impact of 5\%,7.5\%, and 10\% performing loans of particular 1 or 2 sectors directly downgraded to bad/loss category having $100 \%$ provisioning requirement. The fifth deals with the increase of the NPLs due to the default of Top 10 large borrowers and the respective provisioning. The three scenarios shall explain the impact of $5 \%, 7.5 \%$, and $10 \%$ performing loans of Top 10 large borrowers directly downgraded to bad/loss category having $100 \%$ provisioning requirement. The sixth deals with extreme events. Due to an increase in the certain percentage of NPLs, a bank's whole capital position will erase to offset the increased amount of provision due to cover respective loan losses. The forced sale value of the collaterals and tax-adjusted impact of the additional required provision (if any) will be calibrated in the CAR for each scenario under all categories

\section{Correlation Analysis}

Correlation has been run on the variables Loan, Risk weighted asset (RWR), Net profit after Tax (NAPT), classified loan, capital adequacy ratio (CAR), Default rate, ROE. 


\begin{tabular}{|llllllll|}
\hline & Loan & RWA & NAPT & II & CL & CAR & Default rate \\
\hline Loan & 1.000 & & & & & & \\
\hline RWA & 0.9967 & 1.000 & & & & & \\
NAPT & 0.9418 & 0.9229 & 1.000 & & & & \\
II & 0.8854 & 0.8566 & 0.9879 & 1.000 & & & \\
CL & 0.7213 & 0.7555 & 0.4497 & 0.3226 & 1.000 & & \\
CAR & 0.8699 & 0.8321 & 0.9282 & 0.9400 & 0.3773 & 1.0000 & \\
\hline Default rate & -0.9613 & 0.957 & -0.9665 & -0.9284 & -0.564 & -0.89 & 1.000 \\
\hline
\end{tabular}

There exists a strong positive correlation between Loans and Risk-Weighted Assets. So high loan amount will increase the need for high tier 1 capital and tier 2 capital because the risk will increase the weighted risky asset. For Net Profit, after Tax and Risk-Weighted Asset Correlation coefficient is .9229, the result is significant. The risk-weighted asset is mostly formed of debt capital. More debt capital increases the profitability through more interest. So there exists a positive relation. The correlation between NAPT and loans is .9418, and the result is significant. The explanation is as follows. For Interest income\& Loan, the coefficient is .8854. The more unclassified loan, the more interest income. The coefficient between Interest income \& RWA is 8566 , and there exists a strong correlation. In the case of Net profit \& Interest income, the coefficient is .9879 , and there exists a strong correlation. The More the interest, the more the income. The Classified loan \& Loan correlation coefficient is .7214. It indicates a positive and strong correlation. Bur the result is not reliable because the result is insignificant. Normally the more the loan, the more the risk of being classified. The correlation coefficient between Classified loans and RWA is 7555 . So there is a moderately strong relationship between these two variables at a 45 significance level. The more classified loan increases the need to have more provision for it. So the amount of risk-weighted assets increases. The NAPT \& Classified loan has a moderate relationship, but the result is insignificant. Considering the relationship between CAR and Loan, The coefficient is .8699 indicates a strong relationship. But the insignificant result does not provide any reliable answer. The CAR and RWA have a strong coefficient of .8321 .indicates a positive and strong relationship. The more the risk-weighted, the more the requirement of CAR. The coefficient between CAR and NPAT is .9282.indicates a strong positive correlation. More CAR will increase the profitability, decreasing the risk of insufficient capital.

The Default rate and Loan have a correlation coefficient of -0.9613 . So there exists a negative relationship between these two variables. The default rate will decrease with the decrease of the loan. More the RWA, the more the default rate because the volume of the loan amount increases. So the correlation coefficient shows the result of .957. The Interest income and Default rate have a correlation coefficient of -.9284 . There exists a strong negative correlation between these two variables. In reality, the increasing default decreases the interest income. The NAPT and default rate has a coefficient of - .9665 . 
There exists a strong negative correlation between these two variables. In reality, the increasing default decreases the profitability.

\section{Analysis}

This analysis CRM of NCC Bank Ltd. provides very significant insights regarding NCC Bank Limited. The credit Shock impact revealed that NCCBL Bank's adaptability in respect of capital adequacy is stable. NCC Bank has maintained enough capital from the year 2008. And the capital adequacy ratio is now satisfactory. It weights its assets accordingly. It follows the weighted Basel-I accord to weigh its assets according to its risk classes. The capital adequacy ratio (CAR) and minimum capital requirements (MCR) of NCCBL are satisfactory because they maintained the Basel accord standard. The study has calculated some ratios of NCCBL to evaluate its liquidity, profitability, and leverage conditions. The liquidity of NCCBL has been decreased during the year 2020 in terms of the year 2019. Because all the three liquidity ratios (current, cash, and operating cash flow) have been decreased in 2020 . The profitability ratios of NCCBL show that the bank's profitability situation is not so much changed or remained the same as 2019 during the year 2020. Although ROE and ROA have been increased slightly, it indicates profitability condition of NCCBL is in an increasing pattern. The leverage ratios of the bank are satisfactory. Its debtequity and financial leverage conditions have been improved. Debt to total assets and liabilities to equity ratios are slightly decreased. It did not change much during the year 2020 than 2019. But the overall conditions have been slightly improved. The bank is more likely to increase its use of internal capital, increasing efficiency, and profitability. The paid-up capital, the reserve ratio, and the retained earnings have increased with profitability. The default rate has been decreased with the increasing efficiency in credit risk management. The bank has increased its advance/deposit ratio. But it has become the indicator of more profitability, not the default risk because it has been possible for the bank to reduce the default rate. The capital adequacy has been increased, so the investors will be satisfied being ensured about the bank's reliability.

\section{Conclusion}

By considering the overall findings from the analysis, the credit risk management of the bank is good. But the amount of the classified in the figure has to decrease being more concerned. But it should also try to improve the liquidity and profitability conditions of the bank. NCC provides services more efficiently. Its customers are increasing day by day. This bank has captured the part of people who want to invest theirs in the risky sector. If the bank improves efficiency in its operations and customer services, it will increase its profitability and growth in the future.

\section{Declarations}

\section{COMPETING INTERESTS}

The authors declare no competing interests. The author also declares that there exists no conflict of interest. The author didn't receive any grant or funding for this report. All the data are collected from the 
primary sources with the approval from relevant Authority.

\section{References}

1. Abduh, M., Hasan, S., \& Pananjung, A. (2013). Efficiency and performance of Islamic Banks in Bangladesh. Journal of Islamic Banking and Finance, 30(2), 94-106.

2. Ahmed, F. (2021). Assessment of Capital Market Efficiency in COVID-19. European Journal of Business and Management Research, 6(3), 42-46.

3. Ahmed, F. (2021). Corporate Boards, Audit Committees and Voluntary Disclosure: A Case Analysis on Bangladeshi Listed Companies. European Journal of Business and Management Research, 6(2), 153-155.

4. Ahamed, F. (2021). Determinants of Liquidity Risk in the Commercial Banks in Bangladesh. European Journal of Business and Management Research, 6(1), 164-169.

5. Alam, M. Z., \& Musukujjaman, M. (2011). Risk management practices: A critical diagnosis of some selected commercial banks in Bangladesh. Journal of Business and Technology (Dhaka), 6(1), 1535 .

6. Alam, M. (2021). Time Varying Risk in US Housing Sector and Real Estate Investment Trusts Equity Return. Available at SSRN 3893131.

7. Anam, S. et.al. (2012). Liquidity Risk Management: A Comparative Study Between Conventional and Islamic Banks of Bangladesh. Research Journal Economics, Business, ICT. Vol. 5: 1-5

8. Bhuiyan, M. B. U., Salma, U., Roudaki, J., \& Tavite, S. (2020). Financial reporting quality, audit fees and risk committees. Asian Review of Accounting.

9. Khan, M. F. H. (2021). Impact of Exchange Rate on Economic Growth of Bangladesh. European Journal of Business and Management Research, 6(3), 173-175.

10. Lee, C. C., and Hsieh, M. F. (2013), "Beyond bank competition and profitability: Can moral hazard tell us more?" Journal of Financial Services Research, 44(1), 87-109.

11. Mahmoudi, M., \& Ghaneei, H. (2021). Detection of Structural Regimes and Analyzing the Impact of Crude Oil Market on Canadian Stock Market: Markov Regime-Switching Approach. arXiv preprint arXiv:2109.01046.

12. Mahmoudi, M. (2021). Identifying the Main Factors of Iran's Economic Growth using Growth Accounting Framework. arXiv preprint arXiv:2109.02787.

13. Sufian, F., and Habibullah, M. S. (2009), "Determinants of bank profitability in a developing economy: Empirical evidence from Bangladesh," Journal of Business Economics and Management, 10(3), pp. 207-217. 